\title{
DRAWING UP AN INVENTORY OF INTANGIBLE \\ CULTURAL HERITAGE \\ THE AUSTRIAN APPROACH
}

\section{EVA STIERMAYR}

Though the implementation of the UNESCO-Convention in Austria is still in its beginnings, a significant and increasing interest in intangible cultural heritage can be identified. Tradition bearers request help and cooperation to enhance their visibility. A vast number of institutions discover intangible cultural heritage as a new dimension of cultural and research activities, and even public bodies express their interest in discussing issues under this headline.

Keywords: Convention for the Safeguarding of the Intangible Cultural Heritage (UNESCO 2003), inventory of intangible cultural heritage, Austria.
Čeprav je v Avstriji uresničevanje Unescove Konvencije o varovanju nesnovne kulturne dedišcine šele na začetku, je mogoče opaziti pomembno in rastoče zanimanje za nesnovno kulturno dedišcino. Nosilci tradicije prosijo za pomoč in sodelovanje, da bi okrepili svojo vidnost oz. navzočnost $v$ javnosti. Številne ustanove odkrivajo nesnovno kulturno dedišlino kot novo razsežnost kulturnih in raziskovalnih aktivnosti in tudi javne ustanove izražajo interes za razpravljanje o njej.

Ključne besede: Konvencija za varstvo nesnovne kulturne dedišcine (Unesco 2003), popis nesnovne kulturne dedišcine, Avstrija.

As the state parties to the UNESCO 2003 Convention for the Safeguarding of the Intangible Cultural Heritage do have quite a free hand in defining the various elements of intangible cultural heritage present in their territories, it is undoubtedly interesting to reflect on the ways the entrusted bodies pursue and fulfill their obligations. How did Austria decide to draw up its national inventory? What are its experiences and lessons learned?

To support the ratification process and to ensure a smooth implementation once Austria was made State Party, the Austrian Commission for UNESCO set up a separate Division for Intangible Cultural Heritage in 2006. Since then, the Division has been financed through funds made available by the Ministry for Education, Arts and Culture, the Federal Ministry of Agriculture, Forestry, Environment and Water Management, and the Federal Ministry of Health, reflecting the broad concept of culture adopted in UNESCO's definition of intangible cultural heritage.

Three years later, in 2009, Austria ratified the Convention and entrusted the Division to put the Convention into practice, along with inventorying intangible cultural heritage. In order to have a high level of expertise, it established an advisory panel consisting of representatives from five federal ministries, ${ }^{1}$ from the cultural departments of Austria's nine provincial governments and ten scientific experts in the fields of cultural, social, and natural

1 They are in detail the Federal Ministry for Education, Arts and Culture, the Federal Ministry of Agriculture, Forestry, Environment and Water Management, the Federal Ministry of Health, Federal Ministry for European and International Affairs and the Federal Ministry for Economy, Family and Youth. 
sciences. Its main tasks are to decide on the inclusion of traditions into the inventory and to recommend specific traditions, which are perceived to be prestigious and representative for Austria, for the international lists.

Communities, groups, and individuals who pass down practices, knowledge, and skills as part of their cultural heritage represent the most important group involved in drawing up the inventory. Since they themselves have to apply for the inclusion of their practices into the inventory, the Division for Intangible Cultural Heritage drafted an easily accessible and comprehensible application form, resembling the one used for the Representative List of the Intangible Cultural Heritage of Humanity. All information concerning the application process as well as the documents required is available online. ${ }^{2}$

Once the application form, two scientific recommendation letters, and one or more declarations of consent corresponding to the number of the communities concerned have been submitted, the Division for Intangible Cultural Heritage reviews the documents with regard to their completeness and intelligibility. A password-protected online platform allows the members of the advisory panel to examine the applications and ask for clarification if needed. This allows the Division to be well prepared for the meeting of the advisory panel, where decisions have to be made unanimously.

The traditions admitted to the inventory are published in the form of an online database. It includes multi-media based information, as well as dates and events to offer the opportunity to become familiar with Austria's intangible cultural heritage. The applicants of the traditions included are regularly invited to inform the Division about upcoming events. In addition, brochures in German and English are published annually.

At the end of 2011, the Austrian inventory of intangible cultural heritage comprised 50 traditions, which follow the domains of the UNESCO Convention:

(1) Oral traditions and expressions, including language as a vehicle of the intangible cultural heritage

- Classical Horsemanship and the High School of the Spanish Riding School

- The names of farmland in Vorarlberg

- "Roman" - the language of the Romani people of Burgenland

- Names of Slovenian fields and names of houses in Carinthia

- Songs of the Lovara

- Storytelling

- The Ötztal dialect

(2) Performing arts

- Austrian folk dance movement

- Carol singing in Heiligenblut

- Carol singing in the Tyrolian Villgraten Valley (Inner and Outer Villgraten)

2 See: http://immaterielleskulturerbe.unesco.at/ (in German and English) 
- The sword dance of Dürrnberg

- Viennese yodeling

(3) Social practices, rituals and festive events

- "Anklöpfeln" in the Tyrolean lowlands

- Association for mutual assistance in fire emergencies ("ancillary service”)

- "Bloch-pulling" in Fiss

- Bonfire Sunday

- Carnival run of Murau

- Firecracker-shooters of Wirling

- "Glöcklerlauf” in Ebensee

- Hundstoaranggeln

- Imst Carnival - "Schemenlaufen"

- "Lichtbratl"-Monday in Bad Ischl

- Mining culture in Bleiberg

- Mountain fires at the Ehrwalder Talkessel in Tyrol

- "Mullen" and "Matschgern" in the MARTHA villages

- "Niglo"-procession of Windischgarsten

- "Perchten" of Gastein

- Rag procession in Ebensee

- "Samsontragen" in Lungau and Murau

- "Schleicherlaufen" in Telfs

- Shooting clubs in Salzburg

- Silent Night - the Christmas carol

- Tamsweg Union

- Viennese coffee house culture

- Wine guardian procession in Perchtoldsdorf

(4) Knowledge and practices concerning nature and the universe

- Bird catching in Salzkammergut

- Falconry

- Healing knowledge of Pinzgauer men and women

- The knowledge of hazel spruce as tone wood

- Three-step-agriculture in the Bregenz Forest

- Transhumance - the driving of sheep in the Oetztal Alps

(5) Traditional craftsmanship

- Blue printing in Burgenland

- Bodensee's headdress in Lamé lace

- Bread making in the Lesach Valley

- Charcoal burning 
- Forging in Ybbsitz

- Gunsmiths of Ferlach

- Pharmaceutical specialities

- Resin extraction in Lower Austria

- Stove and fireplace masonry in Burgenland

At the same time, the advisory body acknowledged ten traditions which applied for inclusion in the inventory as not being in compliance with UNESCO's definition of intangible cultural heritage. The reasons put forward for exclusion from the inventory include e.g.:

- the tradition bearers cannot be clearly identified as a group;

- the traditions are embedded in a wider context and are thus too small-scale to be included;

- missing declarations of consent;

- the risk of abusing the symbolic capital when acknowledging traditions as in line with UNESCO's perception of intangible cultural heritage;

- recommendation letters that lack an adequate degree of scrutiny.

Since the beginning of the inventory making process, the Division for Intangible Cultural Heritage carefully lists all the decisions of the advisory panel, which is the foundation for both reflection on the reasons for including an application as well as for monitoring of the working processes in general.

For the tradition bearers, being recognized by the Austrian Commission for UNESCO and labelled officially as transmitters of intangible cultural heritage is of great significance. The new-found self-confidence of heritage bearers in Austria has led to a number of publications and projects. Based on the inclusion of "Slovenian field and house names in Carinthia", bilingual maps have been printed in German and Slovenian, a cross-border project launched together with Slovenia, and an internet portal developed in cooperation with the provincial government of Carinthia. The traditions in the inventory are increasingly researched at Austrian universities, such as "Viennese Yodeling", "Story telling", "Bird catching in Salzkammergut", or the link between intangible cultural heritage and tourism.

The surprisingly large amount of media attention induced by the inventory reflects a public interest in intangible cultural heritage. Regional, as well as national newspapers and magazines regularly report on applications in preparation for submission and the results of the advisory body's decisions which contribute substantially to the recognition of communities playing an important role to the safeguarding of intangible cultural heritage and the enrichment of cultural diversity. Beyond the borders of the federal states, decades of primarily voluntary commitment are made visible and help to acknowledge the vital role of communities play in enriching cultural diversity and human creativity.

Besides drawing up an inventory, substantial progress has been achieved in advancing the significance of intangible cultural heritage for health policies, knowledge and practices concerning nature and the universe or tourism. 
With the greatest of efforts, the Division for Intangible Cultural Heritage established a Research Centre for Traditional and Complementary Medicine. ${ }^{3}$ Based on a three year project, the Research Centre aims at providing information about the wide variety of traditional and complementary treatment methods.

The demand for engaging in this field of knowledge and practices concerning nature and the universe rises continuously. The Federal Ministry of Agriculture regularly holds meetings and workshops to explore intangible cultural heritage within agricultural and forestry management. ${ }^{4}$ Specific training courses on forestry and culture were conducted for the first time in 2011 and are by now internationally recognized.

In 2012, the Austrian National Tourist Office focused on intangible cultural heritage within their campaign "Passion for Tradition". 38 traditions were selected in close cooperation with the Division for Intangible Cultural Heritage and - with the agreement of the heritage bearers - carefully made available in form and content for the international markets of the Austrian National Tourist Office. A journal on intangible cultural heritage in Austria, a CD with traditional Austrian music, and video clips rank among the online and printed means of communication. Scientific input was provided by Kurt Luger who was appointed chair holder for the UNESCO Chair for Cultural Heritage and Tourism at the University of Salzburg this year. ${ }^{6}$

Without the strong commitment of many heritage bearers and the advisory panel, who voluntarily offer their expertise, this development would never have been possible.

\section{PRIPRAVA POPISA NESNOVNE KULTURNE DEDIŠČINE. AVSTRIJSKI PRISTOP}

Ker imajo podpisnice Unescove Konvencije za varovanje nesnovne kulturne dediščine razmeroma proste roke pri opredelitvi nesnovne kulturne dediščine na svojem ozemlju, je nedvomno zanimivo premisliti načine, kako odgovorni uresničujejo svoje dolžnosti.

Avstrijska komisija za Unesco je ustanovila poseben Oddelek za nesnovno kulturno dedišcino in mu zaupala popisovanje nesnovne kulturne dediščine. Za visoko strokovno raven je postavljen svetovalni odbor, ki odloča o vključitvi izročil v seznam.

Skupnosti, skupine in posamezniki, ki so prenašalci in posredniki kulturne, so upravičeni, da za seznam prijavijo vključitev svojih praks. V ta namen je Oddelek za nesnovno dediščino pripravil

3 See: http://www.cam-tm.com/ (in German).

4 See: http://www.lebensministerium.at/forst/wald-gesellschaft/Forstkultur/forstkultur_imk.html/ (in German)

5 See: http://www.austria.info/at/leidenschaft-fuer-tradition (in German), http://www.austria.info/uk/ passion-for-tradition/ (in English).

6 See: http://www.unesco.org/en/university-twinning-and-networking/access-by-region/europe-and-north-america/austria/unesco-chair-in-cultural-heritage-and-tourism-941/ (in English). 
preprosto dosegljivo in razumljivo prijavnico. ${ }^{7} Z$ geslom zašćitena spletna aplikacija dovoljuje članom svetovalnega odbora, da preučijo prijave že pred srečanjem odbora, kjer morajo potem soglasno sprejeti odločitve.

Izročilo v popisu je objavljeno v spletni podatkovni zbirki. Poleg tega letno izdajajo brošurice $v$ nemščini in angleščini. Ob koncu leta 2011 je avstrijski popis nesnovne kulturne dediščine vseboval 50 izročil. Oddelek za nesnovno kulturno dediščno je od začetka priprave popisa skrbno navajal vse odločitve svetovalnega odbora, ki so podlaga za premislek o razlogih za vključitev oz. sprejetje predloga.

Priznanje Avstrijske komisije za Unesco je za nosilce tradicije izjemno pomembno. Na novo utemeljena samozavest nosilcev dediščine je spodbudila številne objave in projekte. Zdaj so desetletja dolga prostovoljna prizadevanja vidna tudi prek zveznih deželnih in državnih mej in prispevajo $k$ priznanju vitalne vloge, ki jo imajo skupnosti $v$ bogatenju kulturne raznovrstnosti in človeške ustvarjalnosti.

Poleg postavitve popisa je prišlo do pomembnega napredka pri spodbujanju pomena nesnovne kulturne dedišcine za zdravstveno politiko in prakse, povezane z naravo ter za turizem. $Z$ velikim naporom je Oddelek za nesnovno dedišcino ustanovil Raziskovalni center za tradicionalno in komplementarno medicino. ${ }^{8}$ Zvezno ministrstvo za kmetijstvo redno pripravlja srećanja in delavnice za raziskave nesnovne kulturne dedišcine, pomembne pri upravljanju kmetijstva in gozdarstva. ${ }^{9}$

Z nesnovno kulturno dediščno je bil leta 2012 zaposlen Avstrijski nacionalni turistični urad v akciji "Strast za izročilo «. ${ }^{10}$ V tesnem sodelovanju z Oddelkom za nesnovno kulturno dediščino in s privolitvijo nosilcev dedišcine je izbral 38 izročil za skrbno nadzorovano rabo na mednarodnih tržiščih. Takšen razvoj ne bi bil mogoč brez izjemne privrženosti številnih nosilcev dediščine in svetovalnega odbora, ki prostovoljno nudi svoje strokovno znanje.

Dr. Eva Stiermayr, Assistant Programme Specialist for Intangible Cultural Heritage, Austrian Commission for UNESCO, Universitätsstraße 5/12, A-1010 Wien, Austria, stiermayr@unesco.at

7 Gl. http://immaterielleskulturerbe.unesco.at/ (v nemščini in angleščini).

8 Gl. http://www.cam-tm.com (v nemščini).

9 Gl. http://www.lebensministerium.at/forst/wald-gesellschaft/Forstkultur/forstkultur_imk.html (v nemščini).

10 Gl. http://www.austria.info/at/leidenschaft-fuer-tradition (v nemščini), http://www.austria.info/uk/ passion-for-tradition (v angleščini). 